\title{
Grazing on intertidal microphytobenthos by macrofauna: is pheophorbide $a$ a useful marker?
}

\author{
R. B. Ford*', C. Honeywill
}

Gatty Marine Laboratory, PO Box 349, Warkworth, New Zealand

\begin{abstract}
This study critically evaluates the use of pheophorbide $a$ as a marker pigment for macrofaunal grazing intensity in intertidal sediments. Based upon evidence from planktonic studies pheophorbide $a$ has recently been used to quantify grazing in the sediments; however, no accurate tests have been made of the application of these planktonic concepts to the benthos. Laboratory and field examinations used the cosmopolitan species Arenicola marina, Corophium volutator and Hydrobia ulvae, as well as natural field assemblages from the Eden estuary, Scotland, to examine the relationship between grazing and pigment composition. Faeces from the 3 species were examined using high performance liquid chromatography and showed no sign of pheophorbide $a$, but all species showed concentrations of 'chlorophyll a-like' (chl a) grazing products. In laboratory manipulations, a negative relationship was apparent between grazer numbers and the concentrations of pheophorbide $a$ and grazing products. In the field, pheophorbide $a$ was rarely found but grazing products were present in consistently measurable amounts. When relevant physical and biological factors were regressed against grazing product concentration, a significant relationship was found with an adjusted $\mathrm{R}^{2}$ of 0.76 . This multiple regression used 4 factors to predict chl a degradation concentration; however, the relationship was dominated by a positive relationship with chl a concentration and only 1 of the other 3 factors was directly related to grazing intensity. Neither pheophorbide a nor ' $c h l a-$ like' grazing products were found to be useful as marker pigments of macrofaunal grazing intensity in the intertidal system studied. This places doubt upon the use of pheophorbide a as a marker of macrofaunal grazing intensity in intertidal sediments in past papers, and discourages the use of any marker pigment in estuarine sediments without prior testing.
\end{abstract}

KEY WORDS: Intertidal sediments $\cdot \mathrm{Chl} a \cdot$ Pheophorbide $a \cdot$ Degradation $\cdot$ Grazing $\cdot$ Macrofauna Microphytobenthos $\cdot$ Eden estuary $\cdot$ Scotland

\section{INTRODUCTION}

Estuarine mudflats are one of the most productive natural ecosystems on earth, with a gross primary productivity of up to $10 \mathrm{Kcal} \mathrm{m}^{-2} \mathrm{yr}^{-1}$ (Kennish 1995). These areas are under increasing demographic pressure, with $50 \%$ of the world's population now living within $60 \mathrm{~km}$ of the coast. It is therefore important to try and obtain a baseline of productivity for estuaries against which to judge future anthropogenic and natural effects. Microphytobenthos can be the most important

\footnotetext{
*E-mail: r.ford@auckland.ac.nz
}

producers in this system (Yallop \& Paterson 1994, MacIntyre \& Cullen 1996) supplying up to $45 \%$ of the organic budget of an estuarine coastal system (Asmus et al. 1998). To accurately assess productivity, losses of productivity due to grazing must be quantified.

The concentration of pheophorbide $a$ is one method currently being used to gain insight into relative rates of grazing in intertidal mudflats. Pheophorbide $a$ has been proven to be the degradation product of chlorophyll a (chl a) (an indicator of microphytobenthic biomass) from grazing in the water column (Carpenter et al. 1986, Spooner et al. 1994); however, the application of these findings to the benthos is untested under field conditions. Pheophorbide a has, however, already been 
used in intertidal sediments as an indicator of rates of herbivorous grazing (Brotas \& Plante-Cuny 1998, Lucas \& Holligan 1999). Intertidal areas are, however, more physically dynamic than the water column, being subjected to periods of wet and dry, differing light climates, erosive and/or depositional phases, and differing redox conditions. Chl a grazing products are also known to degrade more rapidly to colourless residues in oxic conditions and when the activity of aerobic organisms are present (Hurley \& Armstrong 1990, Sun et al. 1993a,b). Previous studies using sediments have shown that feeding state of grazers can affect the quantity of chl a grazing products (Abele-Oeschger \& Theede 1991), and that meiofauna can produce pheophorbide a from grazing (Buffan-Dubau et al. 1996). Some of the most commonly cited papers which support the concept of production of pheophorbide $a$ from grazing are, however, unrealistic when compared to anything but dark field conditions, as all the experiments were conducted in the dark (Bianchi et al. 1988, 1991). At present it is therefore unknown how the differing biochemical and biophysical factors operating in intertidal sediments will affect chl $a$ and its grazing products after grazing.

This paper investigates whether grazing of microphytobenthos by 3 common macrofaunal species results in the production of recognised breakdown products, such as pheophorbide a or any other pigment markers. The results will be discussed in terms of the possible extrapolation of its findings to other intertidal systems.

\section{MATERIALS AND METHODS}

Site and experimental macrofauna. All experimental macrofauna and samples were collected from the Eden estuary $\left(56^{\circ} 22^{\prime} \mathrm{N}, 02^{\circ} 51^{\prime} \mathrm{W}\right)$, which is located on the East Coast of Scotland and experiences a maximum tidal range of $4.3 \mathrm{~m}$. Arenicola marina, Corophium volutator and Hydrobia ulvae were chosen for this study because of their numerical dominance in many estuarine mudflats and their probable importance in microphytobenthic grazing. A. marina is a well-known example of a direct deposit feeder that ingests sediment in a burrow at the bottom end of a headshaft 20 to $40 \mathrm{~cm}$ deep (Jacobsen 1967). A. marina defecates at the top of the tailshaft onto the sediment surface (Wells 1953, 1957). C. volutator inhabits U-shaped burrows that extend to a maximum depth of $10 \mathrm{~cm}$ in intertidal muds and ejects materials and faeces from its burrow (Meadows \& Reid 1966, Grant \& Daborn 1994). C. volutator feeds in 3 ways: sifting detritus while moving about on the surface of the substratum, filtering fine particles drawn into the burrow by respiratory currents, or by scraping sediment surrounding the bur- row, and subsequent sifting and ingestion of these particles in the burrow (Hart 1930, Meadows \& Reid 1966). $H$. ulvae is a facultative deposit feeder which grazes at the sediment surface (Newell 1970). H. ulvae does not build a burrow, and egests faeces at the sediment surface (Newell 1970).

Investigations of chl a transformations via grazing by the 3 species above (and others) were undertaken in 3 ways. Firstly, faecal pellets were collected and analysed to identify chl a grazing products. Secondly, laboratory manipulations were completed in systems with and without grazers, and sediments analysed for concentrations of chl $a$, pheophorbide $a$ and any additional grazing products identified by the previous faecal analysis. Thirdly, a survey grid was sampled in the Eden estuary, where many biological and physical measurements were made (horizontal $x$ and $y$ coordinates, mean organic content and mean water content of sediments, pigment concentrations in the sediment, and number and biomass of deposit and nondeposit feeders); these factors were then placed in a multiple regression to determine which factors were most important in determining the concentration of chl a grazing products in the field.

Faecal pellet collection and analysis. Faecal material was collected from Arenicola marina, Corophium volutator and Hydrobia ulvae. Faecal pellets from $C$. volutator and $H$. ulvae were collected under laboratory conditions. Three samples of faecal pellets of 600 individuals were collected from each species. Samples were collected by extracting adult macrofauna directly from ambient sediments into a funnel of seawater ( $5 \mu \mathrm{m}$ filtered) above a $500 \mu \mathrm{m}$ mesh, then leaving them in the dark for over $24 \mathrm{~h}$. Faeces in water were then collected from the base of the funnel after removal of the overlying animals, mesh, and as much water as practicable. Nine A. marina casts were collected from the field in sandy sediments and 10 in muddy sand sediments. Casts were first measured, then separated from the sediment surface using a flat blade, and immediately placed in liquid nitrogen, frozen, and stored at $-80^{\circ} \mathrm{C}$ in the dark to avoid pigment breakdown.

Control samples were collected adjacent to all casts sampled using a contact-corer (Fig. 1). A contact-corer was chosen as it allows rapid sample acquisition of the

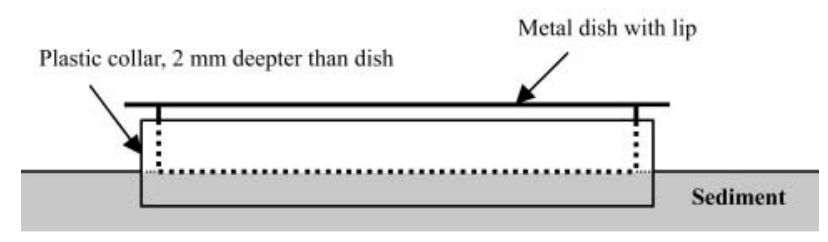

Fig. 1. Diagram of a contact-corer 
sediment's photic zone, where the majority of microalgae are present (Pinckney et al. 1994, Paterson et al. 1998, Wiltshire 2000). A contact-corer flattens and freezes the top 2 to $5 \mathrm{~mm}$ of sediment to a metal surface $56 \mathrm{~mm}$ in diameter. Firstly, the contact-corer is placed firmly on the sediment surface until the metal dish is flush with the sediments. Then, liquid nitrogen is poured into the metal dish of the contact-corer until at least $2 \mathrm{~mm}$ of sediment are frozen. The contact-corer is then removed (including frozen sediment) and the base of the frozen core scraped until the frozen sediment is flush with the plastic collar. Lastly, The 2 to $5 \mathrm{~mm}$ slice of sediment is removed from the contact-corer and wrapped in labelled tin foil. All samples collected were immediately frozen using liquid nitrogen and stored at $-80^{\circ} \mathrm{C}$ in the dark to avoid pigment breakdown.

High performance liquid chromatography (HPLC) analysis was completed on faecal pellets and chl a standards in the laboratory. The aim of this analysis was to quantify the chl $a$, pheophorbide $a$ and 'chl $a$ like' pigments ('chl $a$-like' pigments are hereafter referred to as grazing products). Analysis employed a Waters 700 autosampler and RP C-18 Nucleosil column with an attached Photo Diode Array at $25^{\circ} \mathrm{C}$. Samples were first freeze-dried in the dark. Samples $(\sim 0.1 \mathrm{~g}$ of sediment) were then extracted in the dark at $-80^{\circ} \mathrm{C}$ using $100 \%$ acetone $(\sim 1 \mathrm{ml})$ followed by $90 \mathrm{~min}$ of cold sonication before being run through the column. The sample was run for 40 min sample ${ }^{-1}$ on a methanolbased method shown to achieve good separation of chl pigments, chl breakdown products (including pheophorbide a) and other accessory pigments (Wiltshire \& Schroeder 1994). Three chl a standards (0.0625 to $5 \mathrm{mg} \mathrm{l}^{-1}$ ) were run with each set of samples. Chl $a$ was identified from standards, and pheophorbide from its absorbance spectra and elution order.

Laboratory experiments. Contact-core samples were taken, 15 from grazed and 15 from control treatments after $21 \mathrm{~d}$ in a light (12:12 h) and tidal environment at $10^{\circ} \mathrm{C}$. Grazed treatments (15 replicates) had 10 Nereis diversicolor and 100 Hydrobia ulvae added per core; control treatments (15 replicates) had no macrofauna. Visible grazer mortalities were replaced throughout the $21 \mathrm{~d}$ experiment and grazing was still evident at both the start and end of the experiment in the form of grazing trails. Tides followed ambient patterns for the Eden estuary ( $8 \mathrm{~h}$ immersion, $4 \mathrm{~h}$ emmersion). All experimental replicates were from individual $8 \mathrm{~cm}$ diameter (10 $\mathrm{cm}$ deep) cores. Cores were filled to $8 \mathrm{~cm}$ depth with beach sands (sieved to remove macrofauna with a $2 \mathrm{~mm}$ mesh) then $\sim 2 \mathrm{~cm}$ of homogenised diatom-rich surface sediments (diluted with beach sands) was placed on top of the sand. The homogenised diatomrich surface sediments were surface scrapes from the Eden estuary sieved through a $125 \mu \mathrm{m}$ mesh to elimi- nate larger organisms. The 15 samples for each treatment were analysed by HPLC and differences between treatments in the ratio of grazing products to $\mathrm{chl}$ a examined. As grazing products could be an intermediate stage on the conversion from chl $a$ to pheophorbide $a$, the concentrations of pheophorbide $a$ and grazing products were examined both separately and combined for differences between treatments. Results are displayed either as ratios to $\mathrm{chl} a$ or as peak areas from the HPLC.

Field survey. An integrated sampling programme was completed on the intertidal sediments of the Eden estuary in August 1999, as part of the EU funded BIOPTIS programme (MAS3-CT97-0158). For this analysis, 29 sites were selected that were dominated by microalgae from a sampling grid $600 \mathrm{~m}$ in the across-shore direction and $1000 \mathrm{~m}$ in the downshore direction. This grid encompassed various sediment types and the full range of intertidal height. Measurements taken included mean organic content, mean water content, and percentage of sediments less than $63 \mu \mathrm{m}$ (by weight). Biological samples were taken for pigment analysis by HPLC (extracted via $90 \%$ dimethylformamide or $100 \%$ acetone), the number and percentage of deposit feeders, and the number and percentage of non-deposit feeders as well as a calculated biomass value were all derived from macrofaunal counts.

Measurements were made and results calculated as follows. Horizontal $x$ and $y$ co-ordinates were established via differential GPS (global positioning system). Organic content was calculated from loss of weight on ignition $\left(550^{\circ} \mathrm{C}\right.$ for $\left.6 \mathrm{~h}\right)$ of a randomly selected sub-sample of a homogenised core at each site ( $5 \mathrm{~cm}$ diameter $\times 10 \mathrm{~cm}$ deep), with large shell material removed. Percentage sediments less than $63 \mu \mathrm{m}$ (by weight) were calculated from dry sieving of a randomly selected sub-sample of the same homogenised core at each site $(5 \mathrm{~cm}$ diameter $\times 10 \mathrm{~cm}$ deep) after treatment with sodium hexametaphosphate (Buchanan \& Kain 1971). Mean water content was calculated from the loss of weight on freeze drying of 3 surface slices of the sediment between 2 and $8 \mathrm{~mm}$ deep. Pigments in sediments were quantified using HPLC analysis on contact-core samples as detailed above, only chl $a$, grazing products and pheophorbide a concentrations are discussed here. Numbers and percentages of deposit and non-deposit feeders were calculated from macrofaunal counts $(1 \mathrm{~mm}$ mesh) from a $18 \mathrm{~cm}$ diameter core to a depth of $15 \mathrm{~cm}$ at each site. Arenicola marina were collected by an alternative method; cast counts from three $0.25 \mathrm{~m}^{2}$ quadrats were averaged, normalised to core size and used to estimate the average number of active Arenicola marina. Macrofauna were classified into deposit feeders and non-deposit feeders using the literature and personal observations. 
Macrofaunal biomass was calculated from counts of taxa present (excluding rare macrofauna) in 1 core (18 $\mathrm{cm}$ diameter $\times 15 \mathrm{~cm}$ deep) at each station multiplied by an ash free dry weight (AFDW) for each macrofaunal taxon. Macrofaunal organisms were classified as those retained on a $1 \mathrm{~mm}$ mesh. Arenicola marina were quantified as above. Rare taxa were defined as those present at less than an average of 0.5 individuals core ${ }^{-1}$ and less than an influence of $10 \%$ of numerical abundance for any 1 site. Macrofaunal AFDW per taxon were obtained by averaging weights of animals from the estuary, or from the literature. $A$. marina have by far the largest individual biomass of all animals found in this survey, and are also on average larger at low shore than high shore (Retraubun et al. 1996); therefore, A. marina biomass was calculated on a sliding scale dependent on the shore height. The largest A. marina AFDW was used for the low shore and this was linearly weighted to $10 \%$ of its value for $A$. marina at the high shore. Therefore the calculated weight for the high shore A. marina was $0.015 \mathrm{~g}, 10 \%$ of the weight of the low shore A. marina (0.15 g).

Statistical analyses. A 1-way ANOVA was employed with $\log _{10}(x+1)$ transformations being used where necessary to fulfil model assumptions. Where transformations did not fulfil ANOVA assumptions, a KruskalWallis non-parametric test was used. A stepwise multiple regression analysis was used to assess how much of the variation in grazing products could be correlated to some combination of the other measured factors in the field sampling. Data were $\log _{10}(x+1)$ transformed prior to insertion in the multiple regression model to fulfil the models assumptions.

\section{RESULTS}

\section{Faecal pellet analysis}

Corophium volutator and Hydrobia ulvae faecal material showed measurable quantities of chl a grazing products (Fig. 2a,b). These grazing products were characterised by the Photo Diode Array on the HPLC as having a spectral signature of 2 major absorbance maxima, 1 at 425 to $436 \mathrm{~nm}$, and 1 at 660 to $670 \mathrm{~nm}$. These grazing products were found only in small quantities (a maximum of $60 \%$ of the peak area of chl in any one sample). Chl a standards showed absorbance maxima at 430.8 and $665.4 \mathrm{~nm}$, and a retention time of $24.18 \mathrm{~min}$ on this column. No chl a was found in the faecal samples of either species.

Arenicola marina faecal casts showed the presence of chl $\mathrm{a}$ in addition to the presence of the grazing products seen in the faeces of the other 2 species (Fig. 2c). Comparison of 9 A. marina casts with adjacent sedi- ment in the field showed no significant difference in quantity of chl a $(\mathrm{p}=0.384$, df $=16)$ or grazing products $(\mathrm{p}=0.242$, $\mathrm{df}=16)$ in sand (Fig. 3 ). A similar survey of 10 A. marina casts and adjacent sediment in sandy mud also showed no significant difference in quantity of chl a $(\mathrm{p}=0.185, \mathrm{df}=18)$ or grazing products $(\mathrm{p}=$ 0.57 , df =18). In both comparisons between casts and controls (sand and muddy sand) grazing products of chl a were usually less in faecal samples than in adjacent control samples (Fig. 3).

Ten chl a standards of varying concentrations $(0.06$ to $4.98 \mathrm{mg} \mathrm{l}^{-1}$ ) were run at different times using the same protocol. Chl a grazing products were on average present at $2.5 \%$ of chl a concentrations (over the entire range), with little variance around this mean ( $\sigma=0.2 \%$ of chl a concentrations). This concentration of grazing product was therefore assumed to be an artefact of HPLC processing or chl a storage in acetone, and was subtracted from the concentration of grazing product prior to analysis of data.

No pheophorbide $a$ was detected in the faecal pellets of any of the 3 species.

\section{Laboratory manipulation}

The laboratory experiment showed a strong (but non-significant) trend towards lower levels of chl a grazing products, pheophorbide $a$, and the sum of both of these in grazer treatments compared to ungrazed treatments (Fig. 4, Kruskal Wallis $\mathrm{p}=0.10,0.12,0.44$ respectively). Many zero values for pheophorbide a and grazing product concentrations were recorded in both control and grazer treatments, which attributed to the high variability within treatments. Chl a values were similar for grazer and control treatments (average $=151$ and $149 \mathrm{mg} \mathrm{m}^{-2}$ ) with a high standard deviation (pooled $=136 \mathrm{mg} \mathrm{m}^{-2}$ ); therefore, changes in chl $\mathrm{a}$ were unlikely to be causing this trend of difference in ratios between treatments. The laboratory experiment also showed a significant positive relationship ( $p \leq 0.01$ for all) between the peak areas of chl $a$ and the grazing products, pheophorbide $a$, and grazing products + pheophorbide a (Fig. 5). This means that as chl a increased grazing products, pheophorbide $a$, and grazing products + pheophorbide $a$ all increased as well. These relationships were very loose, however, with the best $r^{2}$ of 0.31 recorded for the relationship between pheophorbide $a$ and chl $a$.

\section{Field survey}

The results from the field survey are summarised in Table 1, and show a large range within both the phys- 


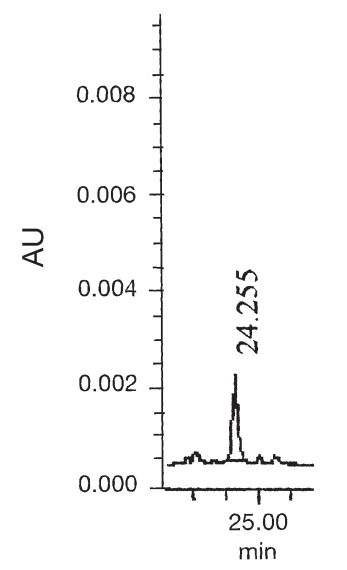

a) Corophium volutator

b) Hydrobia ulvae
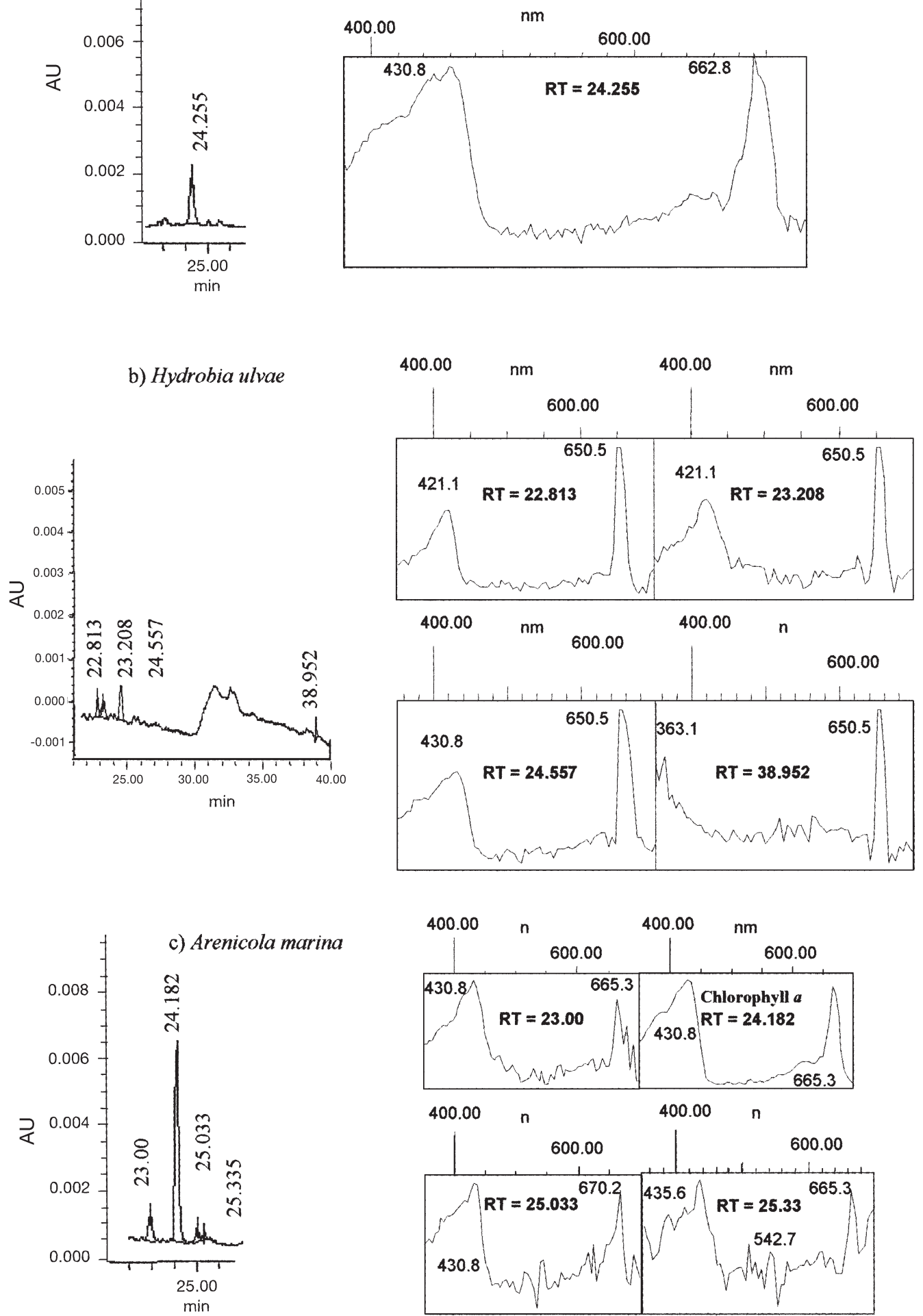

Fig. 2. HPLC absorbance chromatograms at $430 \mathrm{~nm}$ and absorbance spectral signatures (boxed) from faecal samples collected in the laboratory from Corophium volutator and Hydrobia ulvae (a,b) and Arenicola marina in the field (c). Chlorophyll a is shown in part (c) as identified from standards. Only areas of chromatograms are shown where peaks are present (note changes in $x$-axis between $\mathrm{a}, \mathrm{b}$ and $\mathrm{c}$ ). $\mathrm{RT}=$ retention time in minutes 


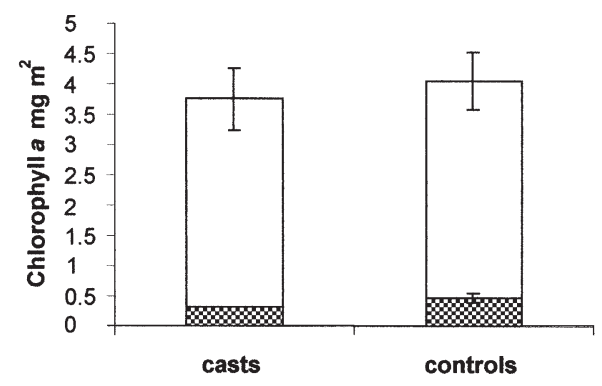

Fig. 3. Chl a concentration (stipled and clear area in boxes) and degradation product concentration (stipled area in relative size to chl a concentration) (shown as relative peak area) in Arenicola casts versus adjacent sediment in the field $(\mathrm{n}=9$, bars $=\mathrm{SD}$ )

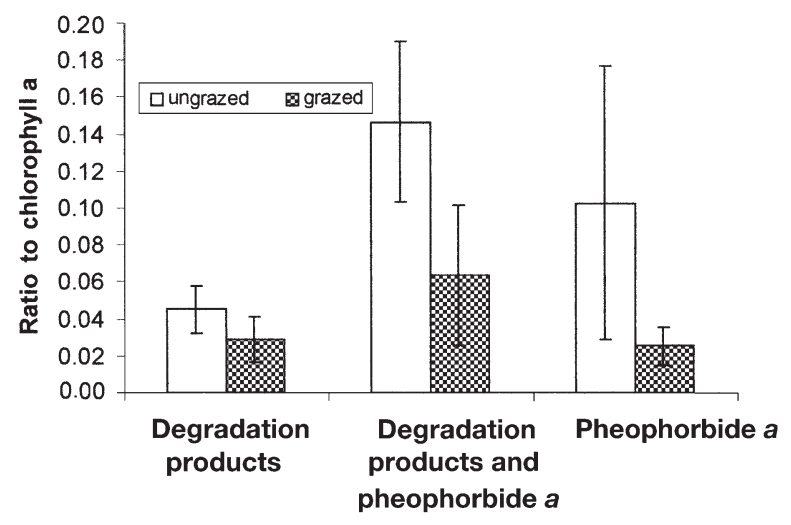

Fig. 4. Ratios of pheophorbide $a$ and grazing products in control and grazer manipulations in laboratory experiment $(\mathrm{n}=$ 15, bars $=\mathrm{SE}$ )

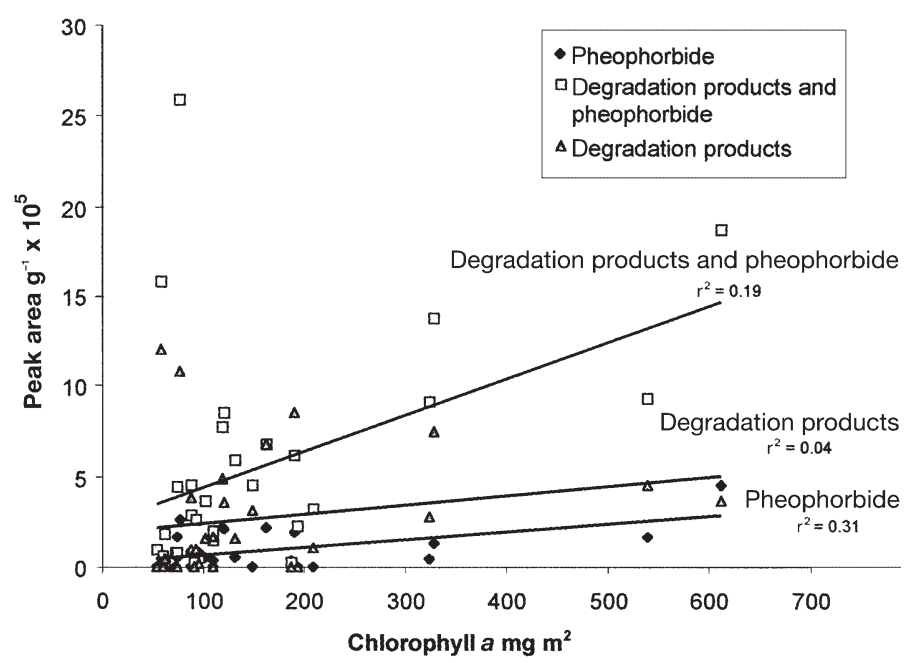

Fig. 5. Regression of chl a content versus grazing products peak area (normalised to weight of sediment) in laboratory experiment ical and biological factors. Organic content varied from 1.3 to $34.0 \%$, with no apparent pattern in response to $x$ or $y$ dimensions. The percentage of cohesive sediments $(<63 \mu \mathrm{m})$ varied from 0.1 to $21.0 \%$, again showing no obvious pattern with spatial dimensions. Water content varied from 11.6 to $90.9 \%$, where sites had standing water. Chl a concentrations varied from 22.4 to $305.9 \mathrm{mg}$ $\mathrm{m}^{-2}$; a similar range of values were recorded from both Northern Europe and the Mediterranean estuarine areas (Colijn \& DeJonge 1984, Barranguet 1997). The ratio of breakdown products to chl a differed over 2 orders of magnitude from a value of 0.002 to 0.267 . Many more deposit feeders compared to other feeding types were present on the Eden tidal flat (maxima of 765 and 174 individuals core ${ }^{-1}$ recorded, respectively). At individual sites percentage composition, however, differed from 0 to $96 \%$ for deposit feeders and 0 to $100 \%$ for non-deposit feeders. The calculated biomass differed from 0 to $1.56 \mathrm{~g}$ of AFDW of carbon per core.

Multiple regression analysis of the factors from the field survey versus chl a grazing products showed a significant relationship $(\mathrm{p}<0.01)$ with an adjusted $\mathrm{r}^{2}$ of 0.76 (Eq. 1):

$\log _{10}($ grazing products $)=1.1065+0.8641\left[\log _{10}(\mathrm{chl} a\right.$ peak area) $]-0.052\left[\log _{10}(\right.$ biomass $\left.)\right]-0.034\left[\log _{10}\right.$ $(\%<63 \mu \mathrm{m})]-0.029\left[\log _{10}\right.$ (distance alongshore)]

The regression equation consisted of a constant, 1 positive dependent variable and 3 negative dependent variables (Eq. 1).

\section{DISCUSSION}

This study realistically addressed chl a breakdown through macrofaunal grazing in estuarine intertidal sediments in the field for the first time. Macrofaunal grazing has been seen to have different affects on chl $a$ depending upon the species studied. In the laboratory, Hydrobia ulvae and Corophium volutator transformed ingested chl a through their grazing activities. Chl a was degraded to form 'chl a-like' compounds (Fig. 2a,b). In contrast, Arenicola marina did not transform chl $a$ or affect chl a concentrations at the sites sampled in the field (Fig. 2c). These findings contrast with previous findings in phytoplankton and sediment samples, where pheophorbide $a$ was found to be the product of grazing on chl a (Abele-Oeschger \& Theede 1991, Head \& Harris 1992, Buffan-Dubau et al. 1996).

The chl a concentrations in the various experiments in this study ranged from 3 to $640 \mathrm{mg} \mathrm{m}^{-2}$ as the sediment changed from almost pure sand (Arenicola marina cast samples) to $<125 \mu \mathrm{m}$ sediment diluted sand (laboratory experiment). These concentrations 
Table 1. Physical and biological variables from the field survey. *Average from 3 replicates

\begin{tabular}{|c|c|c|c|c|c|c|c|c|c|c|c|}
\hline $\begin{array}{l}x \\
\text { (across- } \\
\text { shore, } \\
\text { m) }\end{array}$ & $\begin{array}{c}y \\
\text { (down } \\
\text { shore, } \\
\text { m) }\end{array}$ & $\begin{array}{c}\text { Organic } \\
\text { content } \\
(\%)\end{array}$ & $\begin{array}{c}\text { Sediment } \\
<63 \mu \mathrm{m} \\
(\%)\end{array}$ & $\begin{array}{c}\text { Water } \\
\text { content } \\
(\%)\end{array}$ & $\begin{array}{r}\text { Chl a I } \\
\left(\mathrm{mg} \mathrm{m}_{*}^{-2}\right)\end{array}$ & $\begin{array}{l}\text { Degradation } \\
\text { products } \\
\text { (ratio to } \\
\text { chl a) }\end{array}$ & $\begin{array}{c}\text { Deposit } \\
\text { feeders } \\
\text { (no. } \\
\text { core }^{-1} \text { ) }\end{array}$ & $\begin{array}{l}\text { Other } \\
\text { feeders } \\
\text { (no. } \\
\text { core }^{-1} \text { ) }\end{array}$ & $\begin{array}{c}\text { Deposit } \\
\text { feeders } \\
(\%)\end{array}$ & $\begin{array}{c}\text { Other } \\
\text { feeders } \\
(\%)\end{array}$ & $\begin{array}{c}\text { Biomass } \\
\text { (calculated as g } \\
\text { of AFDW) }\end{array}$ \\
\hline 0 & 0 & 4.9 & 10.1 & 30.5 & 200 & 0.06 & 0 & 0 & 0 & 0 & 0.00 \\
\hline 0 & 100 & 3.5 & 5.4 & 29.9 & 143 & 0.19 & 136 & 58 & 70 & 30 & 0.65 \\
\hline 0 & 200 & 26.9 & 13.3 & 84.7 & 141 & 0.10 & 0 & 0 & 0 & 0 & 0.00 \\
\hline 0 & 900 & 4.1 & 7.1 & 31.9 & 186 & 0.00 & 71 & 10 & 88 & 12 & 0.13 \\
\hline 100 & 0 & 2.8 & 7.8 & 90.8 & 112 & 0.06 & 0 & 0 & 0 & 0 & 0.00 \\
\hline 100 & 100 & 33.9 & 4.5 & 27.3 & 117 & 0.10 & 294 & 53 & 85 & 15 & 0.96 \\
\hline 100 & 900 & 2.7 & 8.1 & 27.3 & 195 & 0.04 & 0 & 0 & 0 & 0 & 0.10 \\
\hline 200 & 0 & 2.8 & 4.7 & 90.9 & 200 & 0.00 & 213 & 42 & 84 & 16 & 0.36 \\
\hline 200 & 100 & 2.4 & 7.0 & 27.2 & 151 & 0.01 & 222 & 31 & 88 & 12 & 0.40 \\
\hline 200 & 200 & 29.3 & 9.5 & 31.8 & 127 & 0.02 & 102 & 43 & 70 & 30 & 0.37 \\
\hline 200 & 700 & 25.2 & 4.7 & 81.9 & 68 & 0.17 & 17 & 0 & 0 & 26 & 0.49 \\
\hline 200 & 900 & 2.3 & 0.1 & 36.9 & 93 & 0.13 & 4 & 19 & 17 & 83 & 0.17 \\
\hline 300 & 0 & 2.6 & 6.4 & 51.0 & 306 & 0.06 & 24 & 41 & 37 & 63 & 0.06 \\
\hline 300 & 100 & 3.7 & 9.3 & 29.5 & 135 & 0.02 & 765 & 34 & 96 & 4 & 1.31 \\
\hline 300 & 200 & 24.9 & 5.7 & 47.0 & 111 & 0.13 & 421 & 134 & 76 & 24 & 1.17 \\
\hline 300 & 600 & 3.7 & 1.4 & 32.5 & 95 & 0.17 & 43 & 66 & 39 & 61 & 1.56 \\
\hline 300 & 700 & 2.1 & 2.5 & 26.2 & 92 & 0.13 & 0 & 0 & 0 & 0 & 0.04 \\
\hline 300 & 800 & 1.5 & 1.0 & 35.8 & 75 & 0.27 & 12 & 10 & 55 & 45 & 0.19 \\
\hline 300 & 900 & 3.9 & 1.1 & 24.8 & 75 & 0.16 & 1 & 30 & 4 & 96 & 0.39 \\
\hline 400 & 100 & 6.7 & 8.9 & 25.8 & 187 & 0.06 & 527 & 47 & 92 & 8 & 0.95 \\
\hline 400 & 200 & 8.0 & 5.6 & 25.5 & 173 & 0.15 & 35 & 31 & 53 & 47 & 0.31 \\
\hline 400 & 600 & 4.0 & 21.0 & 25.7 & 138 & 0.06 & 17 & 48 & 26 & 74 & 1.06 \\
\hline 400 & 800 & 1.3 & 14.2 & 26.0 & 61 & 0.12 & 3 & 1 & 76 & 24 & 0.05 \\
\hline 400 & 900 & 3.2 & 0.4 & 32.1 & 79 & 0.15 & 5 & 14 & 27 & 73 & 0.12 \\
\hline 500 & 100 & 3.2 & 4.5 & 26.0 & 169 & 0.05 & 728 & 48 & 94 & 6 & 1.27 \\
\hline 500 & 200 & 7.7 & 13.4 & 26.3 & 126 & 0.10 & 522 & 30 & 95 & 5 & 0.88 \\
\hline 500 & 700 & 1.5 & 5.3 & 11.6 & 165 & 0.10 & 73 & 174 & 30 & 70 & 0.56 \\
\hline 500 & 800 & 2.5 & 0.9 & 23.7 & 22 & 0.08 & 1 & 6 & 14 & 86 & 0.00 \\
\hline 500 & 900 & 2.9 & 0.4 & 26.3 & 72 & 0.13 & 0 & 8 & 0 & 100 & 0.03 \\
\hline
\end{tabular}

correspond well to a range of estuaries; the Eden estuary has a measured range from 5 to $160 \mathrm{mg} \mathrm{m}^{-2}$ of $\mathrm{chl} \mathrm{a}$ (Honeywill 2001) whilst estuaries in the Netherlands range from these values up to $800 \mathrm{mg} \mathrm{m}^{-2}$ of $\mathrm{chl} a$ (Paterson et al. 1994, Cariou-Le Gall \& Blanchard 1995). These results differed from those of Bianchi et al. $(1988,1991)$, where experiments were conducted in the dark, as all our experiments were conducted using a realistic day:night cycle, which allowed chl a to photo-oxidise. These results also differed from those found for planktonic studies (Carpenter et al. 1986, Head \& Harris 1992, Spooner et al. 1994) as both light and oxygen may not be as readily available in the water column to stimulate photo-oxidation as they are in intertidal surface sediments.

Reworking of sediments by certain macrofauna taxa may increase the breakdown of grazing products and pheophorbide $a$, creating an inverse relationship between grazing and the quantity of these substances. This is suggested by the fact that more grazing products were observed than in controls both in the Areni- cola marina casts in the field (Fig. 3) and in the laboratory experiments with grazers (Fig. 4). This assertion is supported in the literature as chl a grazing products are known to degrade more rapidly to colourless residues when the activity of aerobic organisms is present (Hurley \& Armstrong 1990, Sun et al. 1993a,b). It is, however, unknown how important aerobic breakdown through sediment reworking may be in the field, where it is balanced against the production of grazing products by some species as well as the physically dynamic nature of the habitat.

From the results of the present study the concentrations of grazing products cannot be viewed as suitable markers for grazing pressure in this part of the Eden estuary. The adjusted $r^{2}$ from the multiple regression showed that $76 \%$ of the spatial variation in chl a grazing factors is significantly correlated with 4 factors. The multiple regression equation is dominated, however, by the influence of chl a (an estimator of the biomass of the intertidal microphytobenthos), which contributes $97 \%$ of the $\mathrm{r}^{2}(0.74$ of the 0.76$)$. One expla- 
nation for this pattern is that chl a grazing products isolated from faeces may also be the result of cell senescence. So although grazing is producing chl a grazing products, the signal from the degradation of cells via senescence is dominating the pattern of concentrations in the Eden estuary. In our field experiment, grazing products increased when intertidal microphytobenthos increased, with macrofaunal grazers having only a minimal affect on this relationship.

Of the 3 significant factors (excluding chl a) in the multiple regression, only one of these (macrofaunal biomass) is related to likely macrofaunal grazing intensity. When considered separately from the other 3 physical factors biomass contributed an adjusted $\mathrm{r}^{2}$ of just 0.2 to the multiple regression. However, the direction of this trend is logical and agrees with our findings in the laboratory. As biomass increases the grazing products decrease, probably through reworking of the sediments causing further degradation of these substances into compounds undetectable using HPLC (Hurley \& Armstrong 1990, Sun et al. 1993a,b). This agrees with the trend of decreased breakdown products with increased grazers for our laboratory manipulation (Fig. 4). Distance alongshore and percentage of sediments less than $63 \mu \mathrm{m}$ both also have influences in directions that agree with present literature (Hurley \& Armstrong 1990, Sun et al. 1993a,b). Chl a grazing products decreased as distance alongshore increased, this is in the direction of the estuary mouth, where we would expect more physically turbulent conditions, and hence more exposure of grazing products to oxic conditions and more breakdown. The decrease seen in grazing products with an increase in muds was probably a reflection of the degradation caused by meiofaunal reworking. Meiofauna are usually more abundant in muddy compared to sandy sediments (Coull \& Bell 1979, Coull 1988); therefore, reworking by meiofauna could be expected to increase in muddy sediments and this action could decrease the concentration of grazing products.

There are possible confounding factors in this study that may have affected the detection of any possible relationships with chl a grazing products that should be considered. One possible confounding factor for this relationship is the differential destruction of chl a found in the plankton, but not yet investigated in the benthos. Differential destruction of chl a has been found either within the same species depending upon gut fullness (Vernet \& Lorenzen 1987) or between species (Gieskes et al. 1991, Head \& Harris 1992). Another possible source of error is in the calculation of biomass. When the average biomass value from all sites is spatially scaled up this gives a value of $59.8 \mathrm{~g} \mathrm{~m}^{-2}$. This value allows a broad comparison with the biomass values of Warwick \& Price (1975), which are $13.30 \mathrm{~g} \mathrm{~m}^{-2}$ averaged over a year. Biomass values are higher here, which would be expected when comparing summer values to annual averages, but within the same order of magnitude, which allows some confidence in the calculated biomass values. Meiofaunal grazing has been shown to affect chl a degradation (Buffan-Dubau et al. 1996); however, due to difficulties in collecting sufficient quantities of meiofaunal faeces for HPLC analysis their influence is not investigated here. Another argument that could be raised is cross-correlation between many of the inputted factors from the field survey. Cross-correlation is common between such factors as macrofaunal density and chl $a_{\text {; }}$ concentrations, in that more animals are often found where there is more food in the sediments for deposit feeders. The argument could therefore be raised that the signal from the animals was being masked by the pattern of chl $a_{\text {; }}$ however, in this case no significant regression between chl $a$ and any macrofaunal factors was observed. The production of 'chl a-like' pigments cannot be attributed to methodological problems either, as calibrations showed these pigments to be produced in consistently low quantities $(\sim 2.5 \%)$ as a result of the methodology, well below the concentration of some of the samples $(26.7 \%)$. Therefore these pigment signatures must be the products of macrofaunal grazing and it must be concluded that the link between macrofaunal factors and grazing products was too weak to be of practical use in terms of its use as a marker of macrofaunal grazing. The depth of our sampling (top 2 to $5 \mathrm{~mm}$ ) means this conclusion is especially valid for remote sensing detection of pheophorbides as these platforms only sample the very surface sediments.

Pheophorbide a concentrations in this study were much lower than in many others (Cariou-Le Gall \& Blanchard 1995, Buffan-Dubau et al. 1996, Brotas \& Plante-Cluny 1998); this is probably because in contrast to these previous studies we sampled only the top 2 to $5 \mathrm{~mm}$ of sediment. This is the area where most of the microphytobenthos are present but also is most likely to undergo both photo-oxidation of $\operatorname{chl} a$ and reworking of sediment by the macrofauna. This theory is supported by the pheophorbide concentrations from the study of Barranguet et al. (1997), in which $1 \mathrm{~mm}$ deep surface slices were studied and pheophorbides were only occasionally found at low concentrations. Pheophorbide a was not found in the faeces of any of the 3 macrofaunal organisms studied, or in any of the field samples. This brings into question the use of this pigment to infer grazing rates in intertidal sediments dominated by microphytobenthos elsewhere (Brotas \& Plante-Cuny 1998, Lucas \& Holligan 1999). Given our result, the conclusions drawn from these papers about grazing rates from pheophorbide a concentrations must be questionable. Chl a breakdown pigments may be useful markers of grazing elsewhere, but if high rates 
of biological reworking or deep oxygen diffusion are present this seems unlikely. Therefore, any use of pheophorbide a as a marker pigment for grazing in surface intertidal sediments in the future should be tested prior to use.

Acknowledgements. The authors would like to thank Dr Dave Paterson for his reading and improving of the manuscript. Dr Scot Hagerthy is thanked for his input in helping to design the contact-corer, his processing of the chl a results and statistical advice. Allen Whitaker, Derek Casey and Ruaidhri Carmody are thanked for their collection of the organic matter, GPS positioning and macrofaunal data from the field survey. Derek Casey is also thanked for his macrofaunal sample processing. The input of 3 anonymous referees also helped improve this paper. This work was supported by the EU grant MAS3-CT97-0158 'BIOPTIS'.

\section{LITERATURE CITED}

Abele-Oeschger D, Theede D (1991) Digestion of algal pigments by the common periwinkle Littorina littorea (Gastropoda). J Exp Mar Biol Ecol 147:177-184

Asmus R, Jensen MH, Murphy D, Doerffer R (1998) Primary production of microphytobenthos, phytoplankton and annual yield of macrophytic biomass in the Sylt-Romo Wadden Sea. In: Gätje C, Reise K (eds) Ökosystem Wattenmeer. Springer-Verlag, Berlin, p 367-392

Barranguet C (1997) The role of microphytobenthic primary production in a Mediterranean mussel culture area. Estuar Coast Shelf Sci 44:753-765

Barranguet C, Herman PMJ, Sinke JJ (1997) Microphytobenthos biomass and community composition studied by pigment biomarkers: importance and fate in the carbon cycle of a tidal flat. J Sea Res 38:59-70

Bianchi TS, Dawson R, Sawangwong P (1988) The effects of macrobenthic deposit-feeding on the degradation of chloropigments in sandy sediments. J Exp Mar Biol Ecol 122: 243-255

Bianchi TS, Findlay S, Fontvieille D (1991) Experimental degradation of plant materials in Hudson river sediments I. Heterotrophic transformations of plant pigments. Biogeochemistry 12:171-187

Brotas V, Plante-Cuny MR (1998) Spatial and temporal patterns of microphytobenthic taxa of estuarine tidal flats in the Tagus estuary (Portugal) using pigment analysis by HPLC. Mar Ecol Prog Ser 171:43-57

Buchanan JB, Kain JM (1971) Measurement of the physical and chemical environment. In: Holme NA, McIntyre AD (eds) Methods for the study of marine benthos. Blackwell Scientific Publications, Oxford, p 30-52

Buffan-Dubau E, De Wit R, Castel D (1996) Feeding selectivity of the harpacticoid copepod Canulla perplexa in benthic muddy environments demonstrated by HPLC analyses of chlorin and carotenoid pigments. Mar Ecol Prog Ser 137:71-82

Cariou-Le Gall V, Blanchard GF (1995) Monthly HPLC measurements of pigment concentration from an intertidal muddy sediment of Marennes-Oleron Bay, France. Mar Ecol Prog Ser 121:171-179

Carpenter SR, Elser MM, Elser JJ (1986) Chlorophyll production, degradation, and sedimentation: implications for sedimentology. Limnol Oceanogr 31:112-124

Colijn F, DeJonge VN (1984) Primary production of micro- phytobenthos in the Ems Dollard Estuary. Mar Ecol Prog Ser 14:185-196

Coull BC (1988) Ecology of the marine meiofauna. In: Higgins $\mathrm{RP}$, Thiel H (eds) Introduction to the study of meiofauna, Smithsonian Institute Press, Washington, DC, p 18-38

Coull BC, Bell SS (1979) Perspectives of marine meiofaunal ecology. In: Livingstone RJ (ed) Ecological processes in coastal marine systems. Plenum, New York, p 189-216

Gieskes WWC, Engelkes MM, Kraay GW (1991) Degradation of diatom chl to colourless, non-fluorescing compounds during copepod grazing. Hydrobiol Bull 25:65-72

Grant J, Daborn G (1994) The effects of bioturbation on sediment transport on an intertidal mudflat. Neth J Sea Res 32: $63-72$

Hart TJ (1930) Preliminary notes on the bionomics of the amphipod Corophium volutator (Pallas). J Mar Biol Assoc UK 16:761-789

Head EJH, Harris LR (1992) Chlorophyll and carotenoid transformation and destruction by Calanus spp. grazing on diatoms. Mar Ecol Prog Ser 86:229-238

Honeywill C (2001) In situ analysis of the biomass and distribution of microphytobenthos. PhD thesis, University of St. Andrews, Scotland, UK

Hurley JP, Armstrong DE (1990) Fluxes and transformations of aquatic pigments in Lake Mendota, Wisconsin. Limnol Oceanogr 35:384-398

Jacobsen VH (1967) The feeding of the Lugworm Arenicola marina (L.) quantitative studies. Ophelia 4:91-109

Kennish JK (1995) Ecology of estuaries and anthropogenic effects. CRC Press, London

Lucas CH, Holligan PM (1999) Nature and ecological implications of algal pigment diversity on the Molenplaat tidal flat (Westeschelde estuary, SW Netherlands). Mar Ecol Prog Ser 180:51-64

MacIntyre HL, Cullen JJ (1996) Primary production by suspended and benthic microalgae in a turbid estuary: timescale of variability in San Antonio Bay, Texas. Mar Ecol Prog Ser 145:245-269

Meadows PS, Reid A (1966) The behaviour of Corophium volutator (Crustacea: Amphipoda). J Zool Soc Lond 150:387-399

Newell RC (1970) Biology of intertidal animals. Logos Press Limited, London

Paterson DM, Yallop M, George C (1994) Spatial variability in sediment erodability on the island of Texel. In: Krumbein WE, Paterson DM, Stal LJ (eds) Biostabilization of sediments. BIS Verlag, Oldenburg, p 107-120

Paterson DM, Yates MG, Wiltshire KH, McGroty S, Miles A, Eastwood JA, Blackburn J, Davidson I (1998) Microbiological mediation of spectral reflectance from intertidal cohesive sediments. Limnol Oceanogr 43(6):1207-1221

Pinckney J, Piceno Y, Lovell CR (1994) Short-term changes in the vertical distribution of benthic microalgal biomass in intertidal muddy sediments. Diatom Res 9:143-153

Retraubun ASW, Dawson M, Evans SM (1996) Spatial and temporal factors affecting sediment turnover by the lugworm Arenicola marina (L.). J Exp Mar Biol Ecol 201:23-35

Spooner N, Keely BJ, Maxwell JR (1994) Biologically mediated defunctionalization of $\mathrm{chl}$ in the aquatic environment I. Senesence/decay of the diatom Phaeodactylum tricornutum. Organic Geochem 21:509-516

Sun MY, Lee C, Aller RC (1993a) Anoxic and oxic degradation of ${ }^{14} \mathrm{C}$ labelled chloropigments and a ${ }^{14} \mathrm{C}$ labelled diatom in Long Island Sound sediments. Limnol Oceanogr 38: 1438-1451

Sun MY, Lee C, Aller RC (1993b) Laboratory studies of oxic and anoxic degradation of chl-a in Long-island sound sediments. Geochim Cosmochim Acta 57:147-157 
Vernet M, Lorenzen CJ (1987) The relative abundance of pheophorbide $a$ and pheophytin $a$ in temperate marine waters. Limnol Oceanogr 32:352-358

Warwick RM, Price R (1975) Macrofauna production in an estuarine mud-flat. J Mar Biol Assoc UK 55:1-18

Wells GP (1953) Defaecation in relation to spontaneous activity of Arenicola marina. J Mar Biol Assoc UK 33:51-63

Wells GP (1957) The sources of animal behaviour. Smithsonian Rep 1956:415-429

Editorial responsibility: Otto Kinne (Editor),

Oldendorf/Luhe, Germany
Wiltshire KH (2000) Algae and associated pigments of intertidal sediments, new observations and methods. Limnologica 30:205-214

Wiltshire KH, Schroeder F (1994) Pigment patterns in suspended matter from the Elbe estuary, Northern Germany. Neth J Aquat Ecol 28:255-265

Yallop M, Paterson DM (1994) Survey of the Severn Estuary. In: Krumbein WE, Paterson DM, Stal LJ (eds) Biostabilisation of sediments. BIS Verlag, Oldenburg, p 107-120

Submitted: October 15, 2000; Accepted: May 8, 2001

Proofs received from author(s): February 21, 2002 